\title{
Population Density of the White Bellied Rat, Rattus Rattus Frugivorus in El-Kawther City, Sohag Governorate, Egypt
}

\author{
Abd El-Aleem*, Desoky SS, Ahmed A Sallam and Wael Abd Elbasser M Radwan \\ Plant protection Department, Faculty of Agriculture, Sohag University, Egypt
}

Submission: May 30, 2018, Published: September 06, 2018

"Corresponding author: Abd El-Aleem, Plant protection Department, Faculty of Agriculture, Sohag University, Egypt, Email: abdelalem2011@yahoo.com

\begin{abstract}
The objective of the study is to study the population density of the white bellied rat Rattus rattus frugivorus at the Experimental Station of the Faculty of Agriculture, Sohag University in El-Kawther city, Sohag Governorate, Egypt during 2014-2016 years. The results were showed that the population density of white bellied rat, R.r. frugivorus increases in summer and decreases in winter. It is clear that the sexual ratio decreases in winter, where males are more than females and are active in spring and summer. It was also found that adult males are increasing in the spring and summer seasons, while in females they increase in winter.
\end{abstract}

Keywords: Rattus r. frugivorus; Experimental station; Dominant species; Rodent management programs; White bellied rat

\section{Introduction}

Rodentia is one of the most important mammalian order which has a great numbers of rodent species with their effect on the environment. Directly, through their destructive feeding habits and indirectly by a stable food items for many predators in the food chains. In Egypt changes in the agro-ecosystem, during the last 40 years, have had a great effect on the distribution and abundance of field rodent population [1]. Rodents are implicated in many types of damage, including crop and tree damage, structural property and cable damage, disease transmission [2].

Rats and mice are possibly the most damaging rodents based on economic losses and health-related issues. They are constantly associated with unsanitary habitats, such as sewers and pit latrines and thrive in overcrowded apartments. It has been reported that nearly 4 million rats are born every day and 10 rats for every human alive [3]. This high abundance is expected to lead to more contact between humans and rats resulting more than ever to debilitating rat borne zoonoses with the increased density of human population [4]. In Egypt, the changes of the environment by reclamation the desert and increase the cover plant in this area have been a great effect to the distribution of rodent species on abundance in the studied area $[1,5,6]$.

\section{Materials and Methods}

The present work was carried out in the experimental station of the Faculty of Agriculture, El-Kawther city, Sohag University during 2014-2016 years. It is located in newly reclaimed area at the Eastern desert area as arid region $(15 \mathrm{~km}$. East of Sohag Governorate). This area has been planted from along period about (30 years) with isolated patches of vegetables, wheat, Egyptian clover, alfalfa and certain orchards. 15 wire-box traps were baited and distributed twice every 15 days at $6 \mathrm{pm}$ and collected at $7 \mathrm{am}$. The captured rodents were classified and recorded. The Percentage of every species was estimated as a percent from total rodents captured during the year dominant percentage (D\%).

\section{Results and Discussion}

The results show in the experimental station of the Faculty of Agriculture, El-Kawther city, Sohag University in (Table 1 \& 2) and (Figure $1 \& 2$ ) found that this species ranked the first in abundance among the total rodents population captured in the cultivated area at Sohag constituting $82.84 \%$ and $74.63 \%$ of trapped rodents during 2014/2015 and 2015/2016 respectively. The highest population as assessed trap index occurred during Summer (0.183) and autumn (0.117) equaled by spring (0.158) then winter (0.125) in the first year and Spring (0.091) and Summer (0.146) followed by autumn (0.167) then winter (0.075) in the second year. Inter seasonal variations were noticed with distinct speaks during November (0.05), December (0.1), May (0.212) and July (0.212). The lowest density was observed during November (0.05) and December (0.1) in the first year (Table 1) and (Figure 1). 


\section{Agricultural Research \& Technology: Open Access Journal}

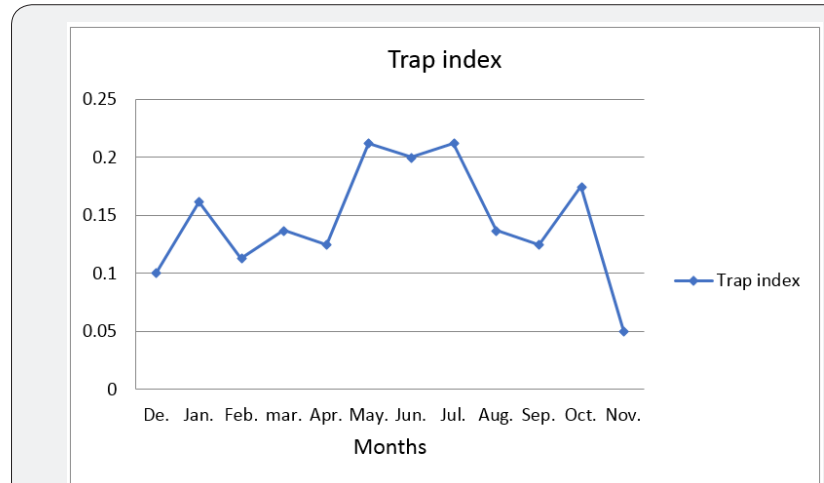

Figure 1: Monthly distribution of R.r. frugivorus in cultivated area during 2014/2015.

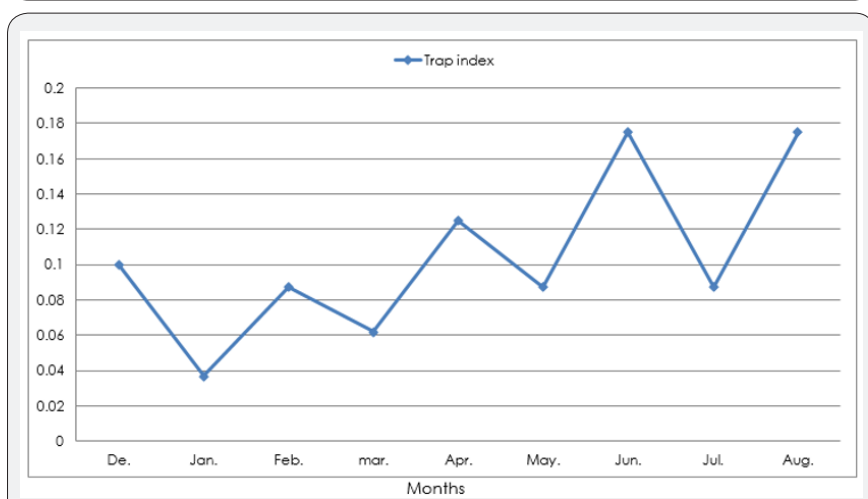

Figure 2: Monthly distribution of R.r. frugivorus in cultivated area during 2015/2016.

In the second year the highest density of rodent population was observed in August (0.175) and June (0.175) and the lowest density was observed in January (0.037), November (0.062) and March (0.062) (Table 2) and (Figure 2). Results of six ratio of this species showed that males slightly outnumbered females during winter and spring, while the reverse was observed in summer and autumn in the first year. The female's ratio was higher than male's ratio during all season, except April and November in the second year. From the same Tables $1 \& 2$ and (Figures $3 \& 4$ ) mature stages surpassed immature stages all over the two years except in April during the first year when reverse occurred. The highest density of immature animals was obtained in December (43.75\%), February (33.33\%), October (28.57\%) and June (27.27\%) during the first year and in April (90.91\%), November (85.71\%) and February (37.50\%) the second year.

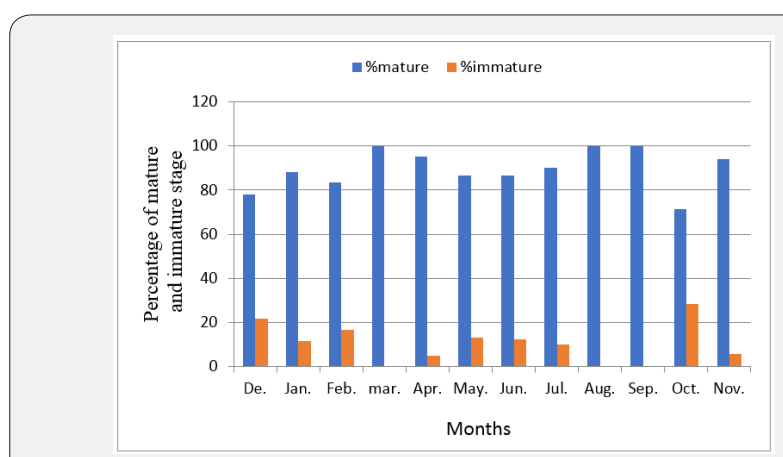

Figure 3: Maturity status of R.r. frugivorus in cultivated area during 2014/2015.

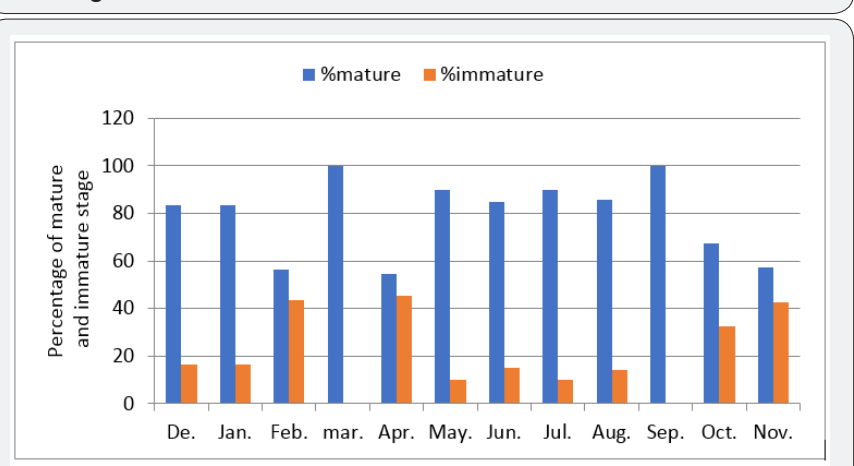

Figure 4: Maturity status of R.r. frugivorus in cultivated area during (2015/2016).

Table 1: Seasonal and monthly fluctuation, trap index, sex ratio and maturity status of R.r. frugivorus in the cultivated area during $2014 / 2015$.

\begin{tabular}{|c|c|c|c|c|c|c|c|c|c|c|c|}
\hline \multirow{4}{*}{$\begin{array}{l}\text { Months } \\
\text { and } \\
\text { Seasons }\end{array}$} & \multirow{4}{*}{$\begin{array}{l}\text { No. of } \\
\text { Rodent }\end{array}$} & \multirow{4}{*}{$\begin{array}{l}\text { Trap } \\
\text { index }\end{array}$} & \multirow{4}{*}{$\begin{array}{c}\text { Males } \\
\%\end{array}$} & \multirow{4}{*}{$\begin{array}{c}\text { Females } \\
\%\end{array}$} & \multicolumn{7}{|c|}{ Maturity Status } \\
\hline & & & & & \multicolumn{2}{|c|}{ Males } & \multicolumn{3}{|c|}{ Females } & \multicolumn{2}{|c|}{ Total } \\
\hline & & & & & \multirow{2}{*}{$\begin{array}{c}\text { Immature } \\
\%\end{array}$} & \multirow{2}{*}{$\begin{array}{c}\text { Mature } \\
\%\end{array}$} & \multirow{2}{*}{$\begin{array}{c}\text { Immature } \\
\%\end{array}$} & \multicolumn{2}{|c|}{ Mature } & \multirow{2}{*}{$\begin{array}{c}\text { Immature } \\
\%\end{array}$} & \multirow{2}{*}{$\begin{array}{c}\text { Mature } \\
\%\end{array}$} \\
\hline & & & & & & & & Preg. \% & $\begin{array}{c}\text { Non } \\
\text { preg. \% }\end{array}$ & & \\
\hline Dec. & 16 & 0.1 & 88.89 & 11.11 & 43.75 & 56.25 & 0 & 50 & 50 & 21.87 & 78.13 \\
\hline Ian. & 26 & 0.162 & 65.38 & 34.62 & 23.53 & 76.47 & 0 & 22.22 & 77.78 & 11.76 & 88.24 \\
\hline Feb. & 18 & 0.113 & 88.89 & 11.11 & 33.33 & 66.67 & 0 & 0 & 100 & 16.67 & 83.33 \\
\hline Winter & 60 & 0.125 & 81.05 & 18.95 & 33.54 & 66.46 & 0 & 24.07 & 75.93 & 16.77 & 83.23 \\
\hline March & 22 & 0.137 & 72.73 & 27.27 & 0 & 100 & 0 & 66.67 & 33.33 & 0 & 100 \\
\hline April & 20 & 0.125 & 66.67 & 33.33 & 10 & 90 & 0 & 60 & 40 & 5 & 95 \\
\hline May & 34 & 0.212 & 67.65 & 32.35 & 17.39 & 82.61 & 9.09 & 36.36 & $54 . .55$ & 13.24 & 86.76 \\
\hline Spring & 76 & 0.158 & 69.02 & 30.98 & 9.13 & 90.87 & 3.03 & 54.34 & 42.63 & 6.08 & 93.92 \\
\hline June & 32 & 0.2 & 68.75 & 31.25 & 27.27 & 72.73 & 0 & 40 & 60 & 13.64 & 86.36 \\
\hline July & 34 & 0.212 & 58.82 & 41.18 & 20 & 80 & 0 & 42.86 & 57.14 & 10 & 90 \\
\hline Aug. & 22 & 0.137 & 27.27 & 72.73 & 0 & 100 & 0 & 37.5 & 62.5 & 0 & 100 \\
\hline Summer & 88 & 0.183 & 51.61 & 48.39 & 15.76 & 84.24 & 0 & 40.12 & 59.88 & 7.88 & 92.12 \\
\hline
\end{tabular}


Agricultural Research \& Technology: Open Access Journal

\begin{tabular}{|c|c|c|c|c|c|c|c|c|c|c|c|}
\hline Sep. & 20 & 0.125 & 30 & 70 & 0 & 100 & 0 & 42.86 & 57.14 & 0 & 100 \\
\hline Oct. & 28 & 0.175 & 100 & 0 & 28.57 & 71.43 & 0 & 0 & 0 & 28.57 & 71.43 \\
\hline Nov & 8 & 0.05 & 89.47 & 10.53 & 11.76 & 88.24 & 0 & 50 & 50 & 5.88 & 94.12 \\
\hline . Autumn & 56 & 0.117 & 73.16 & 26.84 & 13.44 & 86.56 & 0 & 46.43 & 53.57 & 11.48 & 88.52 \\
\hline Mean & 70 & 0.146 & 68.71 & 31.29 & 31.29 & 68.71 & 0.76 & 41.24 & 58 & 10.55 & 89.45 \\
\hline
\end{tabular}

Table 2: Seasonal and monthly fluctuation, trap index, sex ratio and maturity status of R.r. frugivorus in the cultivated area during $2015 / 2016$.

\begin{tabular}{|c|c|c|c|c|c|c|c|c|c|c|c|}
\hline \multirow{3}{*}{$\begin{array}{l}\text { Months } \\
\text { and } \\
\text { Seasons }\end{array}$} & & \multirow{3}{*}{$\begin{array}{l}\text { Trap } \\
\text { Index }\end{array}$} & \multirow{3}{*}{$\begin{array}{c}\text { Males } \\
\%\end{array}$} & \multirow{3}{*}{$\begin{array}{c}\text { Females } \\
\%\end{array}$} & \multicolumn{2}{|c|}{ Males } & \multicolumn{3}{|c|}{ Females } & \multicolumn{2}{|c|}{ Total } \\
\hline & & & & & \multirow{2}{*}{$\begin{array}{c}\text { Immature } \\
\%\end{array}$} & \multirow{2}{*}{$\begin{array}{c}\text { Mature } \\
\%\end{array}$} & \multirow{2}{*}{$\begin{array}{c}\text { Immature } \\
\%\end{array}$} & \multicolumn{2}{|c|}{ Mature } & \multirow{2}{*}{$\begin{array}{c}\text { Immature } \\
\%\end{array}$} & \multirow{2}{*}{$\begin{array}{c}\text { Mature } \\
\%\end{array}$} \\
\hline & & & & & & & & Preg. \% & $\begin{array}{c}\text { Non preg. } \\
\%\end{array}$ & & \\
\hline Dec. & 16 & 0.1 & 92.3 & 7.7 & 33.33 & 66.67 & 0 & 50 & 50 & 16.67 & 83.33 \\
\hline Ian. & 6 & 0.037 & 69.23 & 30.77 & 33.33 & 66.67 & 0 & 25 & 75 & 16.67 & 83.33 \\
\hline Feb. & 14 & 0.087 & 66.67 & 33.33 & 37.5 & 62.5 & 50 & 0 & 50 & 43.75 & 56.25 \\
\hline Winter & 36 & 0.075 & 76.07 & 23.93 & 34.72 & 65.28 & 16.67 & 25 & 58.33 & 25.7 & 74.3 \\
\hline March & 10 & 0.062 & 54.82 & 45.18 & 0 & 100 & 0 & 28.57 & 71.43 & 0 & 100 \\
\hline April & 20 & 0.125 & 73.33 & 26.67 & 90.91 & 9.09 & 0 & 25 & 75 & 45.46 & 54.54 \\
\hline May & 14 & 0.087 & 66.67 & 33.33 & 20 & 80 & 0 & 20 & 80 & 10 & 90 \\
\hline Spring & 44 & $0 . .091$ & 64.94 & 35.06 & 36.97 & 63.03 & 0 & 24.52 & 75.48 & 18.49 & 81.51 \\
\hline June & 28 & 0.175 & 71.43 & 28.57 & 30 & 70 & 0 & 50 & 50 & 15 & 85 \\
\hline July & 14 & 0.087 & 58.82 & 41.18 & 20 & 80 & 0 & 42.86 & 57.14 & 10 & 90 \\
\hline Aug. & 28 & 0.175 & 50 & 50 & 28.57 & 71.43 & 0 & 28.57 & 71.43 & 14.29 & 85.71 \\
\hline Summer & 60 & 0.146 & 60.08 & 39.92 & 26.19 & 73.81 & 0 & 40.48 & 59.52 & 13.1 & 86.9 \\
\hline Sep. & 20 & 0.125 & 40 & 60 & 0 & 100 & 0 & 50 & 50 & 0 & 100 \\
\hline Oct. & 20 & 0.125 & 86.67 & 13.33 & 15.38 & 84.62 & 50 & 0 & 50 & 32.69 & 67.31 \\
\hline Nov & 10 & 0.062 & 93.33 & 6.67 & 85.71 & 14.29 & 0 & 100 & 0 & 42.86 & 57.14 \\
\hline . Autumn & 50 & 0.167 & 73.33 & 26.67 & 33.7 & 66.3 & 16.67 & 50 & 33.33 & 25.18 & 74.82 \\
\hline Mean & 47.5 & 0.112 & 68.6 & 31.4 & 32.9 & 67.1 & 8.33 & 35 & 56.67 & 20.62 & 79.38 \\
\hline
\end{tabular}

Finally, the results were showed that the population density of white bellied rat, R.r. frugivorus increases in spring and summer and decreases in winter. It is clear that the sexual ratio decreases in winter, where males are more than females and are active in spring and summer. It was also found that adult males are increasing in the spring and summer seasons, while in females they increase in winter. This may be due to high pregnancy rat in these months and in the previous months giving chance to high population of immature animals [7]. It was observed that the highest percentage of pregnant females and the high average number of embryos prepregnant female was recorded in winter of the second year. This may be due to the torrent occurring in November 2016 due the compensation of the lost population during the torrent. With exception of winter season during the first year that pregnant females was not trapped. The average number of embryos prepregnant females was found to increase during the decrease of population (Table 1), wholly in agreement with Abdel-Gawad [8].

The results similar with Desoky etal. [9] finding is in agreement with The results show in the experimental station of the Faculty of Agriculture, El-Kawther city, Sohag University, found that the presence of three species of rats included the Lesser garbia,
Gerbillus sp. was recorded (1.08\%) from newly reclaimed area; the Nile grass rat, A. niloticus (4.44\%.) This may be attributed to the availability of food in neighbored field crops and vegetables plantations also, the white bellied rat, R. r. frugivorus the dominant specie (94.27\%).

This may be due to several factors e.g:

a. Intra-specific competition, fecundity increasing and in habitat the ecosystems in which poultry buildings established in the faculty farm the presence of palm trees in the preparation of farm animal production, or poultry farm nearby, this provides shelter and increase in feed stores.

b. Rattus r. frugivorus the dominant species, this may be due to the presence of attributed to the availability of food and shelter as well as prefers trees for nesting nearly from animal production farms and found the inter-specific competition between this species and other species $[5,6]$.

The differences in species composition of rodents depending on locality, neighboring, habitat type, inter specific compotation and preferred food [9]. The objective of the study is to study the population density of the white bellied rat Rattus rattus frugivorus at the study area and its seasonal changes to be used 
in the development of a future plan in effective strategy for implementation of rodent management programs in cultivated and newly reclaimed agro ecosystems in Egypt.

\section{References}

1. El-Sherbiny AH (1987) Cyclic fluctuation in rodent population: Review of current researches. Egypt wild and not resources 19: 17.

2. Witmer G, Campbell EW, Boyd F (1998) Rat management for endangered species protection in the U.S. Virgin Islands. Proceedings of the Vertebrate Pest Conference 18: 281-286.

3. (2003) Rat borne disease on the rise: scientists warn. Health and Medical News.

4. Davis S, Calvet E, Leirs H (2005) Fluctuating rodent population and the risk to human from rodent borne zoonoses. Vector Borne and Zoonotic Diseases 5(4): 305-314.

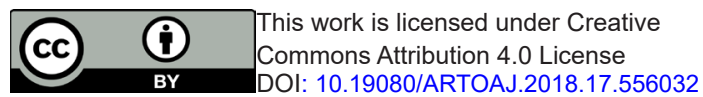

5. Desoky ASS (2007) Management strategies for rodents within different ecosystems. Fac Agric Assiut Univ, Egypt, pp. 124.

6. Abdel-Gawad KH (2010) Rodent species composition in the present compared with past, the 5 Scientific Conferences for Agric Assiut Univ, Egypt, pp. 159-167.

7. Salit AM (1972) Ecological studies on wild and domestic rodents in desert area of Egypt. $1^{\text {st }}$ Sc symp of rodent and their control in Egypt, pp. 61-70.

8. Abdel-Gawad KH (1974) Ecological and toxicological studies on commensal and house hold rodents in Assiut area. Fac Agric Assiut Univ, Egypt.

9. Desoky ASS, Baghdadi SAS, Ahmed HSK (2014) Population density and seasonal distribution of rodent species at sheep farming in El-kawther city, Sohag region, Egypt. J Plant Prot and Path Mansoura Univ 5(10): 903-907.

Your next submission with Juniper Publishers
will reach you the below assets
- Quality Editorial service
- Swift Peer Review
- Reprints availability
- E-prints Service
- Manuscript Podcast for convenient understanding
- Global attainment for your research
- Manuscript accessibility in different formats
( Pdf, E-pub, Full Text, Audio)
- Unceasing customer service
Track the below URL for one-step submission
https://juniperpublishers.com/online-submission.php

